\title{
Preliminary results of the tolerance to inorganic contaminants and phytoextraction potential of twelve ornamental shrub species tested on an experimental contaminated site
}

\author{
Gilles Vincent ${ }^{(1)}$, \\ Kankan Shang ${ }^{(1)}$, \\ Guowei Zhang ${ }^{(1-2)}$, \\ Michel Labrecque ${ }^{(3)}$
}

\begin{abstract}
In urban areas of China, several plant species are commonly used for ornamental purposes. Many of these plants have demonstrated a good capacity to resist these varied urban stresses, and it would be relevant to verify whether they can be grown on polluted sites and demonstrate some phytoremediation potential. Twelve ornamental shrub species were chosen to be tested for tolerance to inorganic contaminants and capacity to absorb and concentrate heavy metals in their aerial parts. A large split-plot trial comprising 20 plots was set up, and soil was spiked with different metals $(\mathrm{Cu}, \mathrm{Pb}$ and $\mathrm{Zn})$. In general, all twelve shrub species performed well regardless of the treatment. Two Hibiscus species, $H$. mutabilis and $H$. syriacus "Hamabo" were particularly productive. In terms of capacity to uptake metals, two of the best performing species were Spiraea japonica, for copper, and Nandina domestica, for lead. Bioconcentration and transfer factors were low. This could be related to weak development of the root systems in these recently established plants. Species with high yield, such as the two Hibiscus species, presented more interesting values in terms of quantity of metal extracted, and could eventually be recommended for decontamination of soils polluted by inorganics.
\end{abstract}

Keywords: Phytoremediation, Phytoectraction, Trace Elements, Ornamental Shrub Species, Urban Stresses

ronmental legislation and increasing support for science and technology in this domain (Han et al. 2016).

Consequently, research aimed at developing new technologies to address soil decontamination have been encouraged and supported by the Shanghai Municipal Greenery and Public Sanitation Bureau. Conventional techniques employed for treating polluted soil include covering it with imported soil, application of lime and chemical washing, and excavation and transport of contaminated soil to landfills. This dig-and-dump approach still constitutes the most common conventional ex situ technology (Kuppusamy et al. 2016). However, all of these approaches are expensive and labour intensive, and can re-
(1) Shanghai Chenshan Botanical Garden, Shanghai 201062 (China); (2) Gansu Agricultural University, Lanzhou 730070 (China); (3) Institut de Recherche en Biologie Végétale, Montreal Botanical Garden, Montreal, QC (Canada)

@ Michel Labrecque (michel.labrecque@umontreal.ca)

Received: Dec 22, 2017 - Accepted: Apr 20, 2018

Citation: Vincent G, Shang K, Zhang G, Labrecque M (2018). Preliminary results of the tolerance to inorganic contaminants and phytoextraction potential of twelve ornamental shrub species tested on an experimental contaminated site. iForest 11: 442-448. - doi: 10.3832/ifor2716-011 [online 2018-06-18]

Communicated by: Werther Guidi Nissim sult in further contamination problems or leaching/deposition of nutrient elements during in situ treatment. It has become a topical research field in the last decade, as it is safe and potentially low cost in comparison to traditional remediation techniques (Garbisu \& Alkorta 2001).

Phytoremediation, and more specifically phytoextraction, is a technique that involves using plants to remove contamination from soil and water. The efficiency of phytoextraction depends on the capacity of the plants to concentrate and accumulate contaminants in their aerial parts. While highly productive species will be more effective for phytoextraction (Kacálková et al. 2014, Courchesne et al. 2017) the actual efficiency of phytoextraction depends primarily on the capacity of plants to establish and survive on contaminated sites (Walter et al. 2003). Consequently, it is important to identify plants well adapted to the urban context and capable of supporting abiotic stresses related to these conditions, specifically water and heat stresses, air pollution, etc.

In urban and peri-urban areas of eastern China, many of the shrub species commonly used for ornamental purposes and planted along highways and boulevards or in parks have demonstrated a very good capacity to resist these varied stresses. Due to their intrinsic characteristics such as perennial, rapid growth and good response to repeated coppicing, woody species are 


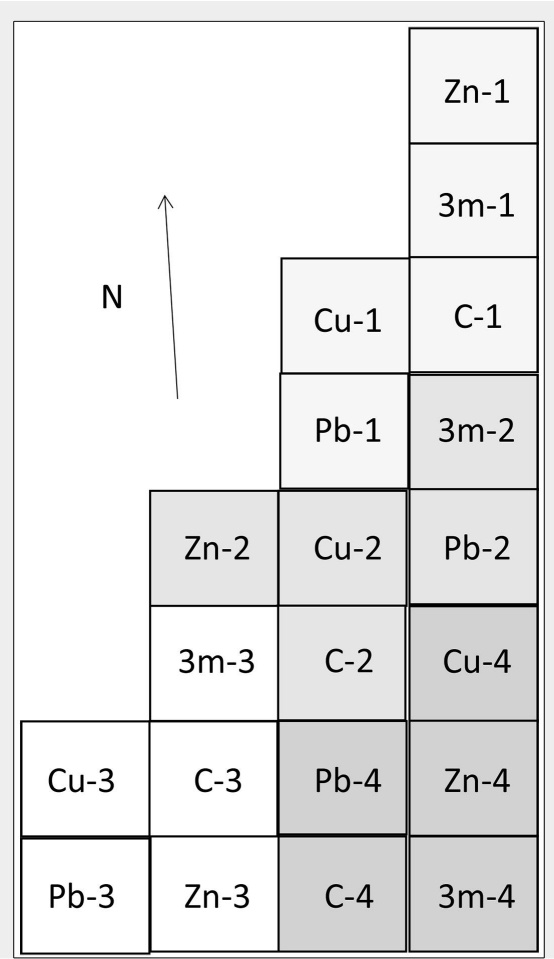

Fig. 1 - Diagram illustrating the split-plot experimental used to conduct the study. It comprised four blocks divided in five $10 \times 10 \mathrm{~m}$ plots, each corresponding to one of the five treatments: soil spiked with $\mathrm{Cu}, \mathrm{Pb}$ or $\mathrm{Zn}$, a treatment containing a mix of those three metals ( $3 \mathrm{~m})$ and a control (C), without contamination.

often recommended for phytoextraction purposes (French et al. 2006). We believe it is relevant to verify whether some of these shrub species may have phytoremediation potential and could be used on polluted soils.

Such a screening trial requires relatively homogenous soil conditions in order to facilitate interpretation. Consequently, this study was carried out in an exceptional experimental context using a large experimental outdoor design to create specific contamination levels under consistent pedoclimatic conditions. Such conditions are not possible on post industrial-use sites that are characterized by precisely such heterogeneous soil and contamination conditions. Studies conducted by Shi et al. (2008) and Wei \& Yang (2010) have shown that urban soils and roadside dust in the Shanghai area are mainly contaminated by $\mathrm{Pb}, \mathrm{Zn}, \mathrm{Cu}, \mathrm{Cr}, \mathrm{Cd}$ and $\mathrm{Ni}$. Since $\mathrm{Cu}, \mathrm{Pb}$ and $\mathrm{Zn}$ were typically found at the highest concentration levels (Shi et al. 2008), these three metals were selected as the focus of the current study.

\section{Methods}

Experimental design and maintenance

The split-plot experimental design consisted of four uniform blocks and was set up on the site of the Chenshan Botanical Garden ( $\left.31^{\circ} 04^{\prime} 39^{\prime \prime} \mathrm{N}, 121^{\circ} 11^{\prime} 12^{\prime \prime} \mathrm{E}\right)$ in Shanghai, China. Shanghai lies in the transitional zone between subtropical and warm temperate zone and has a subtropical monsoon climate. Its average annual temperature is $27.8{ }^{\circ} \mathrm{C}$ with an annual rainfall of $1457.9 \mathrm{~mm}$, of which $60 \%$ is concentrated in the rainy season from May to September (Tian et al. 2015). The soil of the experimental site has been described previously and is a silty clay loam with an elevated $\mathrm{pH}$ of 8 (Wu et al. 2012).

Each of the blocks of the experimental site was divided into five $10 \times 10 \mathrm{~m}$ plots, in which various treatments were randomly applied (Fig. 1). These treatments included spiking the soil with salts of different metals ( $\mathrm{Cu}, \mathrm{Pb}$ and $\mathrm{Zn})$, a treatment containing a mix of the three metals, and a control without contamination. Taking into account the level of the concentrations that can be found on polluted soils and in roadside dust in the Shanghai area (Wei \& Yang 2010), appropriate amount of $\mathrm{CuCl}_{2}, \mathrm{PbCl}_{2}$ and $\mathrm{ZnCl}_{2}$, each in the form of a dry powder, were used to spike the soil for each treatment described above. The diverse metal salts were applied on the soil surface of each plot in the fall, mechanically incorporated into the first 25 to $30 \mathrm{~cm}$ of soil, and left to equilibrate for four months, at which time the shrub species were planted according to the experimental design described above. More details on soil characteristics and means of metal concentrations are presented in Tab. 1.

It should be noted that since this experiment consists of a selection test, it was important to use concentrations that were particularly high, in order to be able to discriminate clearly among the species that were most efficient in the presence of the various contaminants. As well, the entire experimental design of $2000 \mathrm{~m}^{2}$ and the

Tab. 1 - Mean values of $\mathrm{pH}$, conductivity and chemical composition of the soil for each treatment, sampled prior to plantation in the spring of 2015.

\begin{tabular}{lccrrr}
\hline Treatments & $\mathrm{pH}$ & $\mathrm{EC}$ & $\begin{array}{r}\mathrm{CU}_{\text {HNO3 }} \\
(\mathrm{ppm})\end{array}$ & $\begin{array}{r}\mathrm{Pb}_{\text {HNO3 }} \\
(\mathrm{ppm})\end{array}$ & $\begin{array}{r}\mathrm{Zn}_{\text {HNO3 }} \\
(\mathrm{ppm})\end{array}$ \\
\hline Control & 7.99 & 207.0 & 89.26 & 20.03 & 75.50 \\
Cu-spiked soil & 8.04 & 222.5 & 1128.33 & 18.10 & 93.31 \\
Pb-spiked soil & 8.15 & 198.4 & 18.30 & 840.57 & 83.69 \\
Zn-Spiked soil & 8.23 & 191.9 & 22.02 & 26.09 & 3333.74 \\
Cu-Pb-Zn-Spiked soil & 8.03 & 195.2 & 521.12 & 1468.44 & 1300.54 \\
\hline
\end{tabular}

subplots were delimited by plastic barriers staked in the ground to a depth of up to one meter.

The experimental design was not fertilized and was irrigated only twice at the beginning of the experiment following establishment, so as to better evaluate the plant performance with a minimum of intervention. During the growing season, weeding was performed manually twice in June and September.

\section{Shrub species}

A total of twelve shrub species were selected for specific characteristics desirable for effective phytoextraction, notably rapid growth, capacity to resprout after coppicing and good resistance to abiotic and biotic stresses. Special care was taken to include a variety of species, both deciduous and evergreen, belonging to different plant families (Tab. 2 and Fig. 2). Most of the selected species are used extensively in urban landscaping in the city of Shanghai (Liang et al. 2017). The two-year-old seedlings of the shrub species (six per species) were planted randomly in each plot in April 2015, for a total of 1,440 plants ( 6 plants $\times$ 12 species $\times 20$ plots).

\section{Plant samplings}

At the end of November of the first growing season, two plants per treatment per block were randomly harvested to evaluate and compare aerial biomass. Fresh aerial biomass of each sample was weighed in the field using a scale (Xiangshan Cie model ACS-JC21D). A subsample from each plant, consisting of different portions of the stems, was collected and dried at $70^{\circ} \mathrm{C}$ to a constant weight and reweighed to determine moisture content and calculate dry matter yield. These subsamples were then used to evaluate metal concentrations in plant tissues. Roots of each collected specimen were separated, placed in plastic bags and brought to the laboratory for further analysis.

\section{Soil and plant tissue analysis}

Four bulk soil samples (30 $\mathrm{cm}$ topsoil) were collected prior to plantation in spring 2015 and were homogenized and pooled for each plot. Soil samples were air-dried prior to subsequent steps, which involved sieving (2-149 mm mesh). Lead, $\mathrm{Zn}$ and $\mathrm{Cu}$ concentration quantification using $\mathrm{HNO}_{3}$ digestion for $5 \mathrm{~h}$ at $120{ }^{\circ} \mathrm{C}$ and inductively coupled plasma mass spectrometry (Agilent ICPMS $7700^{\circledR}$, Santa Clara, CA, USA). Each soil sample was assessed in duplicate (technical replicates), with method blanks as well as reference material from the Chinese Academy of Measurement Sciences; recovery yields of all peaks ranged from 90\% to $105 \%$ (Kou et al. 2018). Soil pH and electrical conductivity were determined in the supernatants of 1:5 soil and water mixtures using a $\mathrm{pH}$ meter (Hach, Loveland, CO, USA) for electrical conductivity instrument (Leici Company, China). 
The mean concentration values calculated for the spiked plots and presented in Tab. 1 are generally higher than the originally targeted values mentioned above. This may be explained in part by the possibility that incorporation of the metal salts was insufficiently homogeneous or deep. Contamination in the spiked plots was consequently higher than expected, but nevertheless constituted a very good test of the resistance of the selected plants to inorganic pollution.

Rhizospheric soil, i.e., the soil adhering to plant roots (Jaillard et al. 2003), of each of the two samples (per species/treatment/ block), was collected by brushing the roots with a small brush to release soil particles; these were pooled to form one composite sample. The resulting 240 composite samples were analyzed for characterization of soil chemical properties according to the same method described above.

The labile pool of metals or bioavailable fraction of the contaminants was not analyzed in this study. Although this is an important aspect and a determinant indicator from an ecological and toxicological standpoint (Mench et al. 2009), the objective here was primarily to compare plant performance when subjected to identical specific soil conditions.

Above-ground tissues and cleaned roots (rinsed in deionized water, to remove adhering soil particles) were oven-dried at 70 ${ }^{\circ} \mathrm{C}$ until they reached a constant weight. Then, portions of the two samples of aboveground parts as well as roots collected (per species/treatment/block) were mixed and ground with a stainless grinder until all particles passed through a 0.149 $\mathrm{mm}$ nylon sieve for determination of metal content. A total of 240 samples of aboveground tissues and an equal quantity of
Tab. 2 - List of the tested shrub species.

\begin{tabular}{clll}
\hline$\#$ & Species & Family & Life form \\
\hline 1 & Weigelia florida (Bunge) DC “Red Prince” & Caprifoliaceae & Deciduous \\
2 & Spiraea japonica L. & Rosaceae & Deciduous \\
3 & Hibiscus mutabilis L. & Malvaceae & Deciduous \\
4 & Hibiscus syriacus L. "Hamabo” & Malvaceae & Deciduous \\
5 & Salix integra Thunb. "Hakuro Nishiki” & Salicaceae & Deciduous \\
6 & Nerium indicum L. & Apocynaceae & Evergreen \\
7 & Nandina domestica Thunb. & Berberidaceae & Evergreen \\
8 & Euonymus japonicus Thunb. & Celastraceae & Evergreen \\
9 & Pittosporum tobira Banks ex Gaertn. & Pittosporaceae & Evergreen \\
10 & Photinia $\times$ fraseri Dress. & Rosaceae & Evergreen \\
11 & Rhododendrum pulchrum Sweet & Ericaceae & Semi-evergreen \\
12 & Senna corymbosa (Lam.) Irwin \& Barn. & Leguminosae & Semi-evergreen \\
\hline
\end{tabular}

root tissues were constituted. Approximately $0.2 \mathrm{~g}$ of these samples were digested with concentrated $\mathrm{HNO}_{3}(10 \mathrm{ml})$, $30 \% \mathrm{H}_{2} \mathrm{O}_{2}(1 \mathrm{ml})$, concentrated $\mathrm{HCl}(2 \mathrm{ml})$ mixture in Teflon tubes to determine the contents of $\mathrm{Pb}, \mathrm{Cu}$ and $\mathrm{Zn}$. The digested solutions of samples were analyzed using inductively coupled plasma atomic absorption spectrometry (Agilent ICPMS $7700^{\circledR}$ ).

Quality assurance and quality control for soil and plant tissues were assessed using duplicates, method blanks and standard reference materials from the Chinese Academy of Measurement Sciences for each batch of samples ( 1 blank and 1 standard for each 10 samples). The recovery of samples for all metals spiked with standards ranged from $90 \%$ to $105 \%$.

\section{Phytoremediation factors and} quantities of metals extracted

Two indices were used to compare the phytoremediation efficiency of the 12 species: (1) a bioconcentration factor (BCF), defined as the ratio of metal concentration in plant aboveground parts to metal concentration in soil; and (2) a translocation factor (TF) to compare the capacity of plants to translocate the metal absorbed to their aboveground parts. TF is obtained by calculating the ratio between the metal concentrations in aboveground parts to that in root tissues. Quantities of metal exported from the metal-spiked soils were calculated considering the metal concentration in aboveground parts multiplied by the average dry plant dry weight of each species.

\section{Statistical analysis}

All collected data were analysed using mixed-model ANOVA. The model comprised random factor blocks (4), as well as fixed factors - contaminant (5) and species (12). Post-hoc comparisons (Tukey's HSD and $t$-test) were made to contrast the levels of the independent variables, and differences were deemed significant when

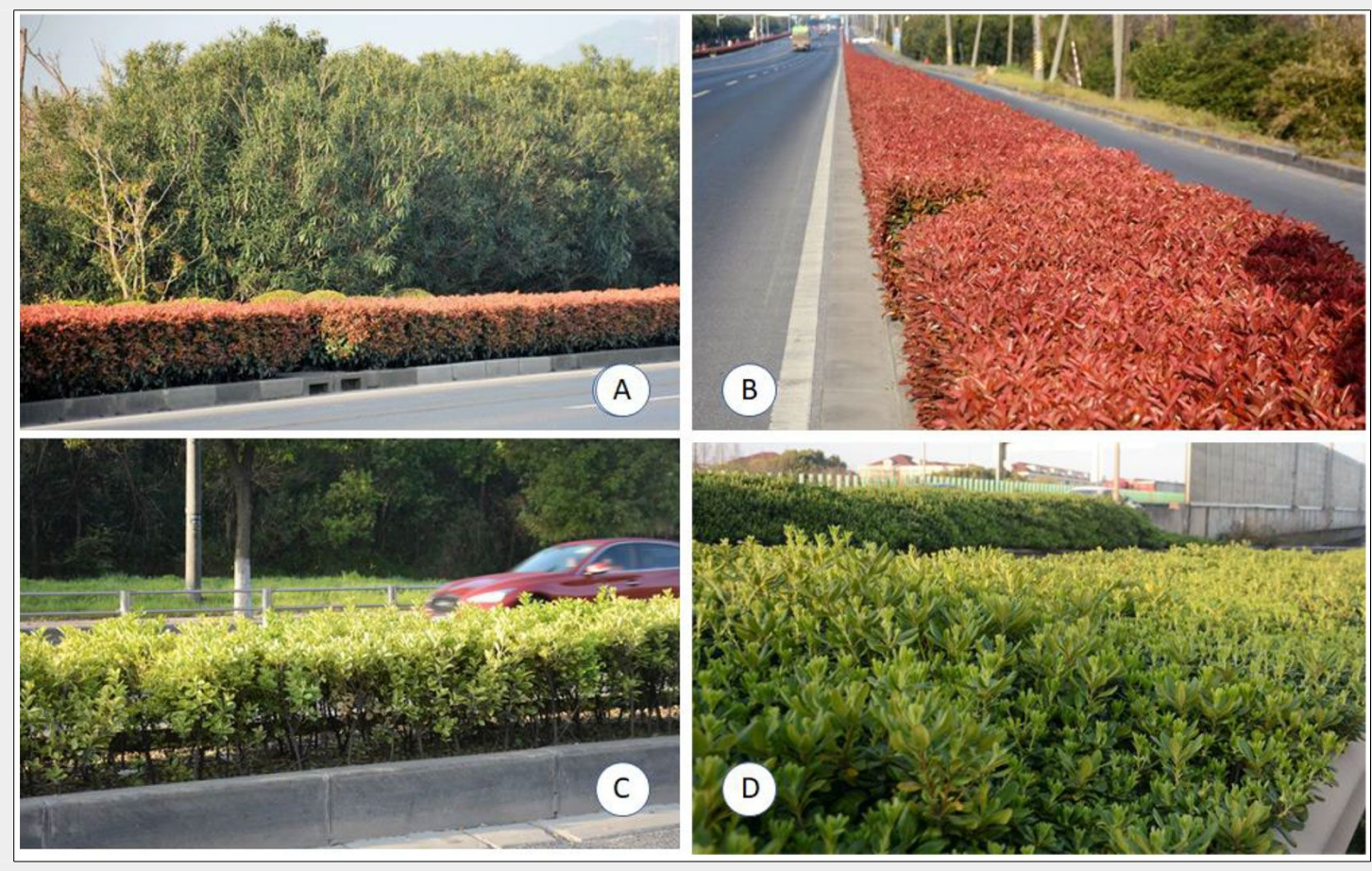

Fig. 2 - Pictures of some of the selected shrub species taken in the urban environment of the City of Shanghai. (A): Nerium indicum (in the background) and Photinia $\times$ fraseri (in the foreground); (B): Photinia $\times$ fraseri; (C): Euonymus japonicus; (D) Pittosporum tobira. 


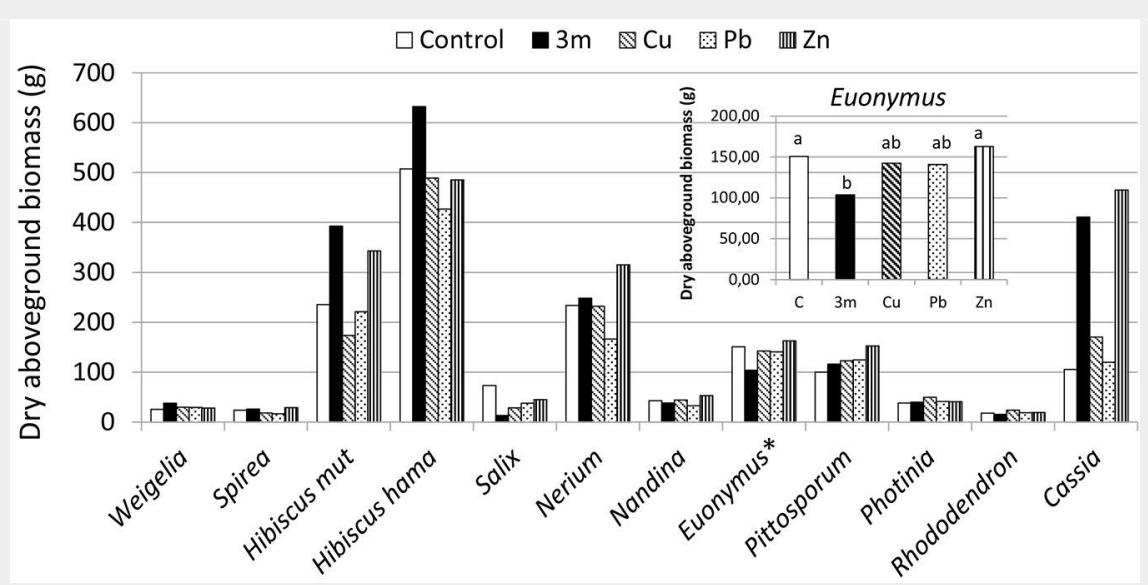

Fig. 3 - Means of dry biomasses for the twelve shrub species after one growing season according to each treatment: soil spiked with $\mathrm{Cu}, \mathrm{Pb}$ or $\mathrm{Zn}$, a treatment containing a mix of those three metals ( $3 \mathrm{~m})$ and a control (C), without contamination. (*): Euonymus japonicus was the only species showing significant changes according to the treatments. Values not connected by same letter are significantly different $(p<0.05)$.

Fig. 4 - Mean concentrations of $\mathrm{Cu}(\mathrm{A}), \mathrm{Pb}(\mathrm{B})$ and $\mathrm{Zn}(\mathrm{C})$ in the plant parts of the twelve shrub species planted in soil spiked with $\mathrm{Cu}, \mathrm{Pb}$ or $\mathrm{Zn}$, and in contro plots (C), without contamination. Species codes: (1): Weigela flor ida "Red Prince";

(2): Spiraea japonica;

(3): Hibiscus mutabilis;

(4): Hibiscus syriacus

"Hamabo"; (5): Salix integra "Hakuro Nishiki"; (6): Nerium indicum; (7): Nandina domestica (8): Euonymus japonicus ; (9): Pittosporum tobira; (10): Photinia $\times$ fraseri; (11): Rhododendron pulchrum; (12) Senna corymbosa. Values not connected by the same letter are sig nificantly different $(p<0.05)$.
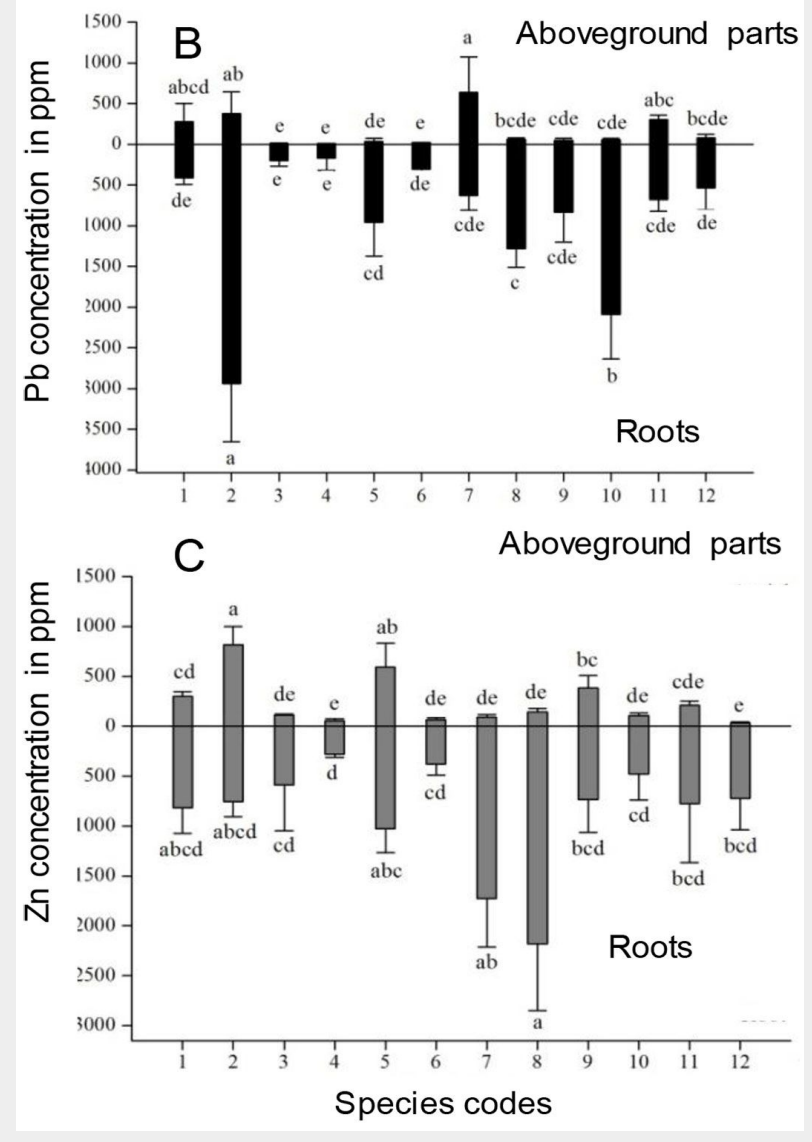

$\mathrm{p}<0.05$. All analyses were performed using $J_{M P^{\circledast}}$ v. 8.0 (SAS Institute, Cary, NC, USA).

\section{Results and discussion}

\section{Comparison of yield}

In general, all plants survived and performed well regardless of the treatment to which they had been exposed. Fig. 3 presents means of dry biomass for the twelve species after one growing season. As each species was of different dimensions at establishment, we can only compare each species according to the diverse treatments; no comparison can be made between species. We observed that soil spiked with the metal salts did not significantly affect the yield of the different plant species. Among all species, only Euonymus japonicus showed a significant reduction of dry aboveground biomass when grown in the plot containing the three metals together and compared to the control. In several cases, and although it was not significant, we even observed better plant performance in metal spiked soils in comparison to control plots. The two Hibiscus species were particularly productive in all experimental treatments. Several Hibiscus species, notably $\mathrm{H}$. cannabinus, have been used frequently in phytoremediation trials and showed good potential to absorb cadmium (Bada \& Raji 2010), chromium (Ogunleye et al. 2016) or lead (Ho et al. 2008) in their tissues. Since plant biomass is a determinant factor for successful phytoextraction and a determinant factor for successful application of phytoremediation (Reeves \& Baker 2000), these preliminary results are encouraging.

\section{Metal concentrations in plant tissues}

Analysis of metal concentrations in aboveground and root tissues provides another picture of the performance of the plants tested (Fig. 4a-Fig. 4C). Plants with the best growth performance were not those presenting the highest metal concentrations in their organs. For copper (Fig. 4a), Spiraea japonica showed the highest concentrations in both aboveground and root tissues $(p<0.05)$. To our knowledge, none of the Spiraea species has been reported as a performing plant for phytoremediation. In this experiment, this plant species presented very poor growth performance in all treatments, including in control plots. It seems that S. japonica was not well adapted to the general conditions of the site and its poor physiological functioning may have resulted in an over absorption of toxic metals (Nouri et al. 2009). The highest lead concentration (Fig. 4b) in aboveground parts was found in Nandina domestica (sacred bamboo), a common Berbiridaceae ornamental plant in China that has become invasive in the USA following its introduction in the 1800 s (Givens 2015). No report was found in the scientific literature about the potential of this species in phytoremediation. However, a very 
high mean concentration of lead (639 ppm) was found in the aboveground parts of these specimens at the end of the first growing season. This is a particularly high value considering that, even in hyperaccumulator plants like Brassica spp., such levels are rarely reported (Baker et al. 1994, Yanqun et al. 2004). The highest concentrations of zinc were again found in S. japonica, but also in Salix integra "Hakuro Nishiki" (Fig. 4C). Failure to thrive in Spiraea plants may also have led to high accumulations of both zinc as well as copper. Results for the Salix cultivar are less surprising. Willows are known for their capacity to absorb and accumulate significant quantities of zinc in their tissues, and there are abundant literature reports of situations where willows have been efficient in absorbing zinc in controlled as well as in field experiments (Bissonnette et al. 2010, Dos Santos Utmazian \& Wenzel 2007, Dos Santos Utmazian et al. 2007, Han et al. 2013, Guidi Nissim et al. 2018).

The metal concentrations measured in stems of some of the plants were comparable to results reported in other studies for species identified as having some potential for phytoextraction. For instance, $\mathrm{Cu}$ concentration in S. japonica compared with the 300 ppm found in stems of Hirschfeldia incana, a Brassicaceae which grows naturally on vineyard soils contaminated with copper (Poschenrieder et al. 2001). Lead concentration in shoots of $\mathrm{N}$. domestica reached $578 \mathrm{ppm}$ (Fig. 4b), a value comparable to those reported for the hyperaccumulators Brassica juncea and B. napus (Lim et al. 2004, Sheng et al. 2008). It should be also pointed out that high $\mathrm{pH}$ values measured in all plots of the experimental site (Tab. 1) have certainly contributed to limit metal uptake by roots (Mench et al. 1994, Alloway 2013, Kidd et al. 2015).

In a similar study conducted over a threemonth period on a site polluted by high levels of contaminants at comparable concentrations to those used in our study, Zhuang et al. (2007) tested eight different herb species. They found much lower concentrations in the aerial plant part tested. For instance, the highest concentrations of lead (146 ppm) was found in Dianthus sinensis, a value two to four times lower than the concentrations detected in S. japonica and $N$. domestica respectively. Since shrub species with higher productivity were selected in the present study, we can anticipate that greater quantities of metal will also be extracted from the contaminated soil.

In plots where the three metals were combined, concentrations of copper, lead and zinc were generally higher in root tissues for all plants tested (Fig. 5). The highest concentration, although not statistically significant, was observed in Euonymus japonicus. In both roots and aboveground tissues, metal concentrations were generally lower in comparison to levels observed when plots were spiked with only one metal. Again, S. japonica was revealed to

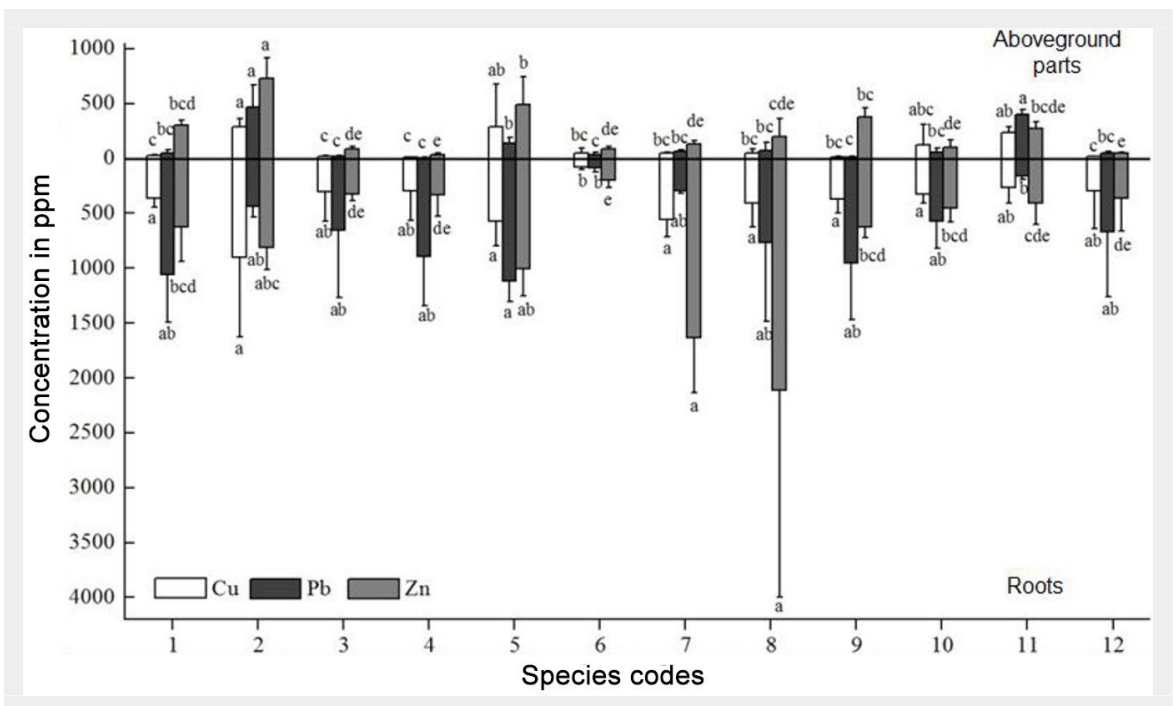

Fig. 5 - Mean concentrations of $\mathrm{Cu}, \mathrm{Pb}$ and $\mathrm{Zn}$ in aboveground parts and roots of the twelve shrub species planted in plots contaminated with a mix of those three metals at the end of the first growing season. Species codes: (1): Weigela florida "Red Prince"; (2): Spiraea japonica; (3): Hibiscus mutabilis; (4): Hibiscus syriacus "Hamabo"; (5): Salix integra "Hakuro Nishiki"; (6): Nerium indicum; (7): Nandina domestica; (8): Euonymus japonicus; (9): Pittosporum tobira; (10): Photinia $\times$ fraseri; (11): Rhododendron pulchrum; (12): Senna corymbosa. Values not connected by the same letter are significantly different $(\mathrm{p}<0.05)$.

be the best performing species in concentrating the three metals in its aboveground parts, while, curiously, N. domestica had a very low $\mathrm{Pb}$ concentration. It is quite plausible that the combination of the three metals in high concentrations in the same edaphic environment affected the sorption and absorption of those elements and consequently plant capacity to absorb them (Lasat 2000).

\section{Bioconcentration factor}

The bioconcentration factor is defined as the ability of a plant to take up and transport metals to its aboveground parts, which can be harvested to discharge the soil of the contaminant. BCFs were calculated at the end of the first growing season for all species, and results are reported in Tab. 3. An efficient plant for phytoextraction should have a BCF superior to 1 (Yan-

Tab. 3 - Bioconcentration factors calculated for each shrub species at the end of the first growing season. Values not connected by same letter are significantly different $(p<0.05)$.

\begin{tabular}{lccc}
\hline Species & Cu-spiked soil & Pb-spiked soil & Zn-spiked soil \\
\hline Weigela florida "Red Prince" & $0.023^{\mathrm{c}}$ & $0.073^{\mathrm{bcd}}$ & $0.094^{\mathrm{cd}}$ \\
Spiraea japonica & $0.108^{\mathrm{a}}$ & $0.106^{\mathrm{ab}}$ & $0.256^{\mathrm{a}}$ \\
Hibiscus mutabilis & $0.010^{\mathrm{c}}$ & $0.003^{\mathrm{e}}$ & $0.035^{\mathrm{ef}}$ \\
Hibiscus syriacus "Hamabo" & $0.011^{\mathrm{c}}$ & $0.002^{\mathrm{e}}$ & $0.017^{\mathrm{f}}$ \\
Salix integra "Hakuro Nishiki" & $0.019^{\mathrm{c}}$ & $0.009^{\mathrm{cde}}$ & $0.182^{\mathrm{b}}$ \\
Nerium indicum & $0.006^{\mathrm{c}}$ & $0.005^{\mathrm{de}}$ & $0.021^{\text {ef }}$ \\
Nandina domestica & $0.013^{\mathrm{c}}$ & $0.169^{\mathrm{a}}$ & $0.028^{\mathrm{ef}}$ \\
Euonymus japonicus & $0.016^{\mathrm{c}}$ & $0.016^{\mathrm{cde}}$ & $0.044^{\mathrm{ef}}$ \\
Pittosporum tobira & $0.008^{\mathrm{c}}$ & $0.013^{\mathrm{cde}}$ & $0.121^{\mathrm{c}}$ \\
Photinia $\times$ fraseri & $0.007^{\mathrm{c}}$ & $0.014^{\mathrm{cde}}$ & $0.034^{\mathrm{ef}}$ \\
Rhododendron pulchrum & $0.053^{\mathrm{b}}$ & $0.076^{\mathrm{bc}}$ & $0.062^{\mathrm{de}}$ \\
Senna corymbosa & $0.018^{\mathrm{c}}$ & $0.026^{\mathrm{cde}}$ & $0.010^{\mathrm{f}}$ \\
\hline
\end{tabular}

qun et al. 2004). In this study, BCFs of the tested plants were extremely low. The highest BCFs calculated were for S. japonica, for which BCFs varied between 0.1 for $\mathrm{Cu}$ and $\mathrm{Pb}$ and 0.26 for $\mathrm{Zn}$. These low factors could be related to the state of development of the plants and, in particular, to the weak development of the root systems in recently established plants. The fact that the metal concentrations in the spiked plots were very high (1128, 840 and 2453 $\mathrm{ppm}$ for $\mathrm{Cu}, \mathrm{Pb}$ and $\mathrm{Zn}$, respectively) certainly played a role in producing these low values.

\section{Translocation factors}

The translocation factor refers to the efficiency of the plant in translocating the accumulated metal from its roots to shoots (Ali et al. 2013). In phytoremediation, plants with a TF superior to 1 are suitable. 
Tab. 4 - Transfer factors calculated for each shrub species at the end of the first grow ing season. Values not connected by same letter are significantly different $(p<0.05)$.

\begin{tabular}{lccc}
\hline Species & Cu-spiked soil & Pb-spiked soil & Zn-spiked soil \\
\hline Weigela florida “Red Prince" & $0.166^{\mathrm{bcd}}$ & $0.694^{\mathrm{ab}}$ & $0.384^{\mathrm{c}}$ \\
Spiraea japonica & $0.313^{\mathrm{ab}}$ & $0.123^{\mathrm{d}}$ & $1.079^{\mathrm{a}}$ \\
Hibiscus mutabilis & $0.233^{\mathrm{bc}}$ & $0.057^{\mathrm{d}}$ & $0.274^{\mathrm{cd}}$ \\
Hibiscus syriacus "Hamabo" & $0.082^{\mathrm{d}}$ & $0.045^{\mathrm{d}}$ & $0.193^{\mathrm{de}}$ \\
Salix integra "Hakuro Nishiki" & $0.134^{\mathrm{cd}}$ & $0.031^{\mathrm{d}}$ & $0.059^{\mathrm{b}}$ \\
Nerium indicum & $0.146^{\mathrm{cd}}$ & $0.067^{\mathrm{d}}$ & $0.180^{\mathrm{de}}$ \\
Nandina domestica & $0.094^{\mathrm{cd}}$ & $0.995^{\mathrm{a}}$ & $0.062^{\mathrm{e}}$ \\
Euonymus japonicus & $0.087^{\mathrm{cd}}$ & $0.049^{\mathrm{d}}$ & $0.069^{\mathrm{e}}$ \\
Pittosporum tobira & $0.094^{\mathrm{cd}}$ & $0.070^{\mathrm{d}}$ & $0.586^{\mathrm{b}}$ \\
Photinia $\times$ fraseri & $0.034^{\mathrm{d}}$ & $0.026^{\mathrm{d}}$ & $0.267^{\mathrm{cd}}$ \\
Rhododendron pulchrum & $0.385^{\mathrm{a}}$ & $0.450^{\mathrm{bc}}$ & $0.226^{\mathrm{cde}}$ \\
Senna corymbosa & $0.151^{\mathrm{cd}}$ & $0.238^{\mathrm{cd}}$ & $0.049^{\mathrm{e}}$ \\
\hline
\end{tabular}

Transfer factors were calculated for the twelve species tested in this study and are presented in Tab. 4. The majority of TFs was below 1 and was over or close to 1 only in N. domestica for lead, and S. japonica for zinc. TFs for copper were in general lower than those calculated for lead and zinc. Considering all species, we calculated a TF mean (results not shown) of 0.16 for copper. The mean value for zinc was twice as high (0.29). The transfer factor is a major criterion for identifying plants that can be used in phytoremediation, and it would therefore be interesting to see how N. domestica will perform after several growing seasons in soil contaminated by lead.

\section{Quantity of metal extracted by plants}

The quantity of metal taken up from the soil by plants can be calculated by multiplying its concentration in the aboveground parts by the dry weight of these portions. Total quantities of metal take up were calculated for all tested plants, are expressed in milligrams and presented in Tab. 5 .

As results are influenced by the biomass produced, this provides yet another picture for comparison with data presented in Fig. 4. In general, plants that have grown well will take up superior quantities of metal (Fig. 4 and Tab. 5). This was the case for the two Hibiscus species (for copper and zinc) and Pittosporum tobira (for zinc). More surprisingly, and despite their weak biomass production, $\mathrm{N}$. domestica (for lead) and S. japonica (for the three metals) were among the best performing species. Willows also extracted relatively high quantities of zinc, although their biomass production was among the lowest of all plants. The same patterns were generally observed for plots contaminated with the mix of the three metals. It should be emphasized that there were few statistical differences between the values for different plant species as presented in Tab. 5. This was due to the high variance demonstrated by the statistical analysis.

\section{Conclusions}

This study reports preliminary results on early performance of twelve ornamental Chinese shrub species selected for their growth characteristics and capacity to support repeated harvesting. Plants were followed during a first growing season and evaluated for their capacity to uptake inorganic contaminants from soil spiked with copper, lead and zinc. In general, plants did not present signs of phytotoxicity after seven months of growth and demonstrated fairly normal development and growth. This is relevant information, considering the objective of this work, which was to identify species resistant to urban conditions and able to colonize contaminated areas. Some species clearly grew better than others. The two Hibiscus species and Senna corymbosa performed particularly well in all spiked plots.

In terms of capacity to uptake metals, Spiraea japonica and Nandina domestica were revealed to be two of the best performing species. To our knowledge, the phytoremediation potential of these taxa has never been reported in the literature. If their general performance continues or improves over the coming growing seasons, these two species could be considered for the revegetation of polluted sites, particularly those contaminated with lead.

Calculated quantities of metal extracted after one growing season were very small. In the best situation, it was estimated that only a few dozen mg could be extracted over the initial growing season following establishment. Results for copper and lead were particularly weak, but for zinc, values were significantly higher. This parameter is largely controlled by growth performance. The species with high yield, such as the two Hibiscus species, presented more interesting values in terms of quantity of metal extracted, and could also be among the species that could eventually be recommended for decontamination of soils polluted by inorganics.

\section{Acknowledgments}

Our thanks to Stéphane Daigle for assistance with statistical analysis and to Karen Grislis for her critical review of the manuscript. We would also like to thank the Shanghai Chenshan Botanical Garden for the implementation of the study site and providing us access to it. This work was financially supported by grant from the Shanghai Administration Bureau of Landscape and City Appearance (Grant No. G152426, G162415).

Tab. 5 - Mean values in $\mathrm{mg}$ of copper, lead and zinc extracted by the shrub species after one growing season. Values not connected by same letter are significantly different $(p<0.05)$.

\begin{tabular}{|c|c|c|c|c|c|c|}
\hline \multirow{2}{*}{ Species } & \multicolumn{3}{|c|}{ Soils spiked by one metal } & \multicolumn{3}{|c|}{ Soils spiked with the three metals } \\
\hline & Cu-spiked soil & Pb-spiked soil & Zn-spiked soil & $\mathrm{Cu}$ & $\mathrm{Pb}$ & Zn \\
\hline Weigela florida "Red Prince" & $1.15^{\mathrm{b}}$ & $5.30^{a b c}$ & $8.82^{\mathrm{cd}}$ & $0.66^{b}$ & $1.31^{\mathrm{b}}$ & $8.40^{\mathrm{bcd}}$ \\
\hline Spiraea japonica & $2.93^{\mathrm{ab}}$ & $4.18 \mathrm{abc}$ & $20.28 \mathrm{abc}$ & $6.78^{a}$ & $10.61^{\mathrm{a}}$ & $16.02^{a b}$ \\
\hline Hibiscus mutabilis & $3.14^{\mathrm{ab}}$ & $2.07^{\mathrm{bc}}$ & $31.05^{\mathrm{ab}}$ & $6.97^{\mathrm{a}}$ & $6.05^{\mathrm{ab}}$ & $30.21^{\mathrm{a}}$ \\
\hline Hibiscus syriacus "Hamabo" & $8.00^{a}$ & $2.79 \mathrm{abc}$ & $17.35^{a b c}$ & $4.50^{\mathrm{ab}}$ & $3.59 \mathrm{ab}$ & $16.83^{a b}$ \\
\hline Salix integra "Hakuro Nishiki" & $0.85^{\mathrm{b}}$ & $0.76^{c}$ & $22.77^{a b c}$ & $1.01^{\mathrm{b}}$ & $1.48^{\mathrm{b}}$ & $4.69^{\mathrm{cd}}$ \\
\hline Nerium indicum & $1.95^{\mathrm{ab}}$ & $3.19 \mathrm{abc}$ & $15.88^{\mathrm{bc}}$ & $7.77^{\mathrm{a}}$ & $6.11^{\mathrm{ab}}$ & $15.27 \mathrm{abc}$ \\
\hline Nandina domestica & $0.50^{\mathrm{b}}$ & $15.58^{\text {a }}$ & $3.49^{d}$ & $1.22^{\mathrm{b}}$ & $2.14^{\mathrm{b}}$ & $3.80^{d}$ \\
\hline Euonymus japonicus & $2.88^{a b}$ & $8.11^{\mathrm{ab}}$ & $21.12^{a b c}$ & $2.38^{\mathrm{ab}}$ & $4.32^{\mathrm{ab}}$ & $14.53^{a b c}$ \\
\hline Pittosporum tobira & $1.20^{\mathrm{b}}$ & $5.08 \mathrm{abc}$ & $51.40^{\mathrm{a}}$ & $0.95^{\mathrm{b}}$ & $1.40^{\mathrm{b}}$ & $39.29^{a}$ \\
\hline Photinia $\times$ fraseri & $0.54^{\mathrm{b}}$ & $1.78^{\mathrm{bc}}$ & $3.71^{d}$ & $1.54^{\mathrm{ab}}$ & $1.52^{\mathrm{b}}$ & $2.52^{d}$ \\
\hline Rhododendron pulchrum & $1.52^{\mathrm{ab}}$ & $5.27 \mathrm{abc}$ & $3.14^{d}$ & $3.32^{\mathrm{ab}}$ & $5.86^{\mathrm{ab}}$ & $3.50^{d}$ \\
\hline Senna corymbosa & $3.65^{a b}$ & $5.78^{\mathrm{ab}}$ & $10.66^{\mathrm{bcd}}$ & $5.12^{\mathrm{ab}}$ & $13.94^{\mathrm{a}}$ & $14.29 \mathrm{abc}$ \\
\hline
\end{tabular}




\section{References}

Ali H, Khan E, Sajad MA (2013). Phytoremediation of heavy metals - concepts and applications. Chemosphere 91 (7): 869-881. - doi: 10.1016/j.chemosphere.2013.01.075

Alloway BJ (2013). Heavy metals in soils: trace metals and metalloids in soils and their bioavailability. In: "Environmental pollution ( ${ }^{\text {rd }}$ edn)". Springer, Netherlands, pp. 613.

Bada BS, Raji KA (2010). Phytoremediation potential of kenaf (Hibiscus cannabinus L.) grown in different soil textures and cadmium concentrations. African Journal of Environmental Science and Technology 4 (5): 250-255. [online] URL: http://www.ajol.info/index.php/ajest/arti cle/view/56356

Baker AJM, Reeves RD, Hajar ASM (1994). Heavy metal accumulation and tolerance in British populations of the metallophyte Thlaspi caerulescens J. and C. Presl (Brassicaceae). New Phytologist 127: 61-68. - doi: 10.1111/j.1469-8137.19 94.tbo4259.x

Bissonnette L, St-Arnaud $M$, Labrecque $M$ (2010). Phytoextraction of heavy metals by two Salicaceae clones in symbiosis with arbuscular mycorrhizal fungi during the second year of a field trial. Plant and Soil 332 (1-2): 55-67. - doi: 10.1007/s11104-009-0273-x

Branigan T (2014). Chinese premier declares war on pollution in economic overall. The Guardian, $6^{\text {th }}$ March, 2014. [online] URL: http://www.the guardian.com/world/2014/mar/05/china-pollu tion-economic-reform-growth-target

Courchesne F, Turmel MC, Cloutier-Hurteau B, Constantineau S, Munro L, Labrecque M (2017). Phytoextraction of soil trace elements by willow during a phytoremediation trial in southern Québec, Canada. International Journal of Phytoremediation 19 (6): 545-554. - doi: 10.1080/152 26514.2016.1267700

Dos Santos Utmazian MN, Wenzel WW (2007). Cadmium and zinc accumulation in willow and poplar species grown on polluted soils. Journal of Plant Nutrition and Soil Science 170 (2): 265272. - doi: 10.1002/jpln.200622073

Dos Santos Utmazian MN, Wieshammer G, Vega R, Wenzel WW (2007). Hydroponic screening for metal resistance and accumulation of cadmium and zinc in twenty clones of willows and poplars. Environmental Pollution 148 (1): 155165. - doi: 10.1016/j.envpol.2006.10.045

French CJ, Dickinson NM, Putwain PD (2006). Woody biomass phytoremediation of contaminated brownfield land. Environmental Pollution 141: 387-395. - doi: 10.1016/j.envpol.2005.08.065 Garbisu C, Alkorta I (2001). Phytoextraction: a cost-effective plant-based technology for the removal of metals from the environment. Bioresource Technology 77 (3): 229-236. - doi: 10.1016/S0960-8524(00)00108-5

Givens RL (2015). A botanical survey of native and non-native species along the Three Rivers Greenway in Columbia, South Carolina. Master's thesis, University of South Carolina, SC, USA, pp. 24. [online] URL: http://search. proquest.com/openview/a4d69052820fc3c032 dcbc1017eaa301/1

Guidi Nissim W, Palm E, Mancuso S, Azzarello E (2018). Trace element phytoextraction from contaminated soil: a case study under Mediterranean climate. Environmental Science and Pol- lution Research 25 (9): 9114-9131. - doi: 10.1007/ s11356-018-1197-x

Han D, Currell, MJ, Cao G (2016). Deep challenges for China's war on water pollution. Environmental Pollution 218: 1222-1233. - doi: 10.101 6/j.envpol.2016.08.078

Han SH, Kim DH, Shin SJ (2013). Bioaccumulation and physiological response of five willows to toxic levels of cadmium and zinc. Soil and Sediment Contamination 22 (3): 241-255. - doi: 10.1080/15320383.2013.726290

Ho WM, Ang LH, Lee DK (2008). Assessment of $\mathrm{Pb}$ uptake, translocation and immobilization in kenaf (Hibiscus cannabinus L.) for phytoremediation of sand tailings. Journal of Environmental Sciences 20 (11): 1341-1347. - doi: 10.1016/S10010742(08)62231-7

Jaillard B, Plassard C, Hinsinger P (2003). Measurements of $\mathrm{H}^{+}$fluxes and concentrations in the rhizosphere. In: "Handbook of Soil Acidity" (Rengel Z ed). CRC Press, Boca Raton, FL, USA, pp. 231-266. [online] URL: http://www.taylor francis.com/books/e/9780203912317

Kacálková L, Tlustos P, Száková J (2014). Chromium, nickel, cadmium, and lead accumulation in maize, sunflower, willow, and poplar. Polish Journal of Environmental Studies 23 (3): 753761. [online] URL: http://www.pjoes.com/pdf/ 23.3/Pol.J.Environ.Stud.Vol.23.No.3.753-761.pdf Kidd P, Mench M, Alvarez-López V (2015). Agronomic practices for improving gentle remediation of trace element-contaminated soils. International Journal of Phytoremediation 17 (11): 1005-1037. - doi: 10.1080/15226514.2014.1003788 Kou S, Vincent G, Gonzalez E, Pitre FE, Labrecque $M$, Brereton NJB (2018). The response of a $16 \mathrm{~S}$ ribosomal RNA gene fragment amplified community to lead, zinc and copper pollution in a Shanghai field trial. Frontiers in Microbiology 9: 496. - doi: 10.3389/fmicb.2018.00366 Kuppusamy S, Palanisami T, Megharaj M, Venkateswarlu K, Naidu R (2016). In-situ remediation approaches for the management of contaminated sites: a comprehensive overview. Reviews of Environmental Contamination and Toxicology 236: 1-115. - doi: 10.1007/978-3-31920013-2_1

Lasat $M \bar{M}$ (2000). Phytoextraction of metals from contaminated soil: a review of plant/soil/ metal interaction and assessment of pertinent agronomic issues. Journal of Hazardous Substance Research 2 (5): 1-25.

Liang J, Fang HL, Zhang TL, Wang XX, Liu YD (2017). Heavy metal in leaves of twelve plant species from seven different areas in Shanghai, China. Urban forestry and Forest Greening 27: 390-398. - doi: 10.1016/j.ufug.2017.03.006 Lim JM, Salido AL, Butcher DJ (2004). Phytoremediation of lead using Indian mustard (Brassica juncea) with EDTA and electrodics. Microchemical Journal 76 (1): 3-9. - doi: 10.1016/j.mi croc.2003.10.002

Mench M, Vangronsveld J, Didier V, Clijsters H (1994). Evaluation of metal mobility, plant availability and immobilization by chemical agents in a limed-silty soil. Environmental Pollution 86 (3): 279-286. - doi: 10.1016/0269-7491(94)901686

Mench M, Schwitzguébel JP, Schroeder P, Bert V, Gawronski S, Gupta S (2009). Assessment of successful experiments and limitations of phy- totechnologies: contaminant uptake, detoxification and sequestration, and consequences for food safety. Environmental Science and Pollution Research 16 (7): 876-900. - doi: 10.1007/ s11356-009-0252-z

Nouri J, Khorasani N, Lorestani B, Karami M, Hassani $\mathrm{AH}$, Yousef $\mathrm{N}$ (2009). Accumulation of heavy metals in soil and uptake by plant species with phytoremediation potential. Environmental Earth Sciences 59 (2): 315-323. - doi: 10.1007/s12665-009-0028-2

Ogunleye JA, Dagari MS, Balogun OL, Maigari A (2016). Effect of oxalic acid on $\mathrm{Cr}^{3+}$ ion uptake, accumulation and oxidative stress by Sorrel ( $\mathrm{Hi}$ biscus sabdariffa L.) seedlings in hydroponic solution. International Journal of Chemical, Material and Environmental Research 3 (3): 49-55. [online] URL: http://www.researchgate.net/pu blication/307888835

Poschenrieder C, Bech J, Llugany M, Pace A, Fenés E, Barceló J (2001). Copper in plant species in a copper gradient in Catalonia (North East Spain) and their potential for phytoremediation. Plant and Soil 230 (2): 247-256. - doi: 10.1023/A:1010374732486

Reeves RD, Baker A (2000). Metal-accumulating plants. In: "Phytoremediation of toxic metals" (Raskin I, Ensley BD eds). Wiley, New York, USA, pp. 304.

Sheng X, Xia JJ, Jiang CY, He LY, Qian M (2008). Characterization of heavy metal-resistant endophytic bacteria from rape (Brassica napus) roots and their potential in promoting the growth and lead accumulation of rape. Environmental Pollution 156 (3): 1164-1170. - doi: 10.1016/j.env pol.2008.04.007

Shi G, Chen Z, Xu S, Zhang J, Wang L, Bi C, Teng J (2008). Potentially toxic metal contamination of urban soils and roadside dust in Shanghai, China. Environmental Pollution 156: 251-260. doi: 10.1016/j.envpol.2008.02.027

Tian ZH, Song K, Da LJ (2015). Distribution patterns and traits of weed communities along an urban-rural gradient under rapid urbanization in Shanghai, China. Weed Biology and Management 15: 27-41. - doi: 10.1111/wbm.12062

Walter R, Keller C, Boschi K (2003). Phytoextraction capacity of trees growing on a metal contaminated soil. Plant Soil 256: 265-272. - doi: 10.1023/A:1026100707797

Wei BG, Yang LS (2010). A review of heavy metal contaminations in urban soils, urban road dusts and agricultural soils from China. Microchemical Journal 92: 99-107. - doi: 10.1016/j.microc.20 09.09 .014

Wu HB, Fang HL, Peng HL, Liang J, Hu YH, Cai YP, Hao GJ (2012). Soil physical properties analysis of the typical newly established green belt of Shanghai Chenshan Botanical Garden. Journal of Soil and Water Conservation 26 (6): 85-90.

Yanqun Z, Yanqun Z, Yuan L, Schwartz C, Langlade $L$, Fan $L$ (2004). Accumulation of $\mathrm{Pb}, \mathrm{Cd}$, $\mathrm{Cu}$ and $\mathrm{Zn}$ in plants and hyperaccumulator choice in Lanping lead-zinc mine area, China. Environment International 30 (4): 567-576. doi: 10.1016/j.envint.2003.10.012

Zhuang P, Yang QW, Wang HB, Shu WS (2007). Phytoextraction of heavy metals by eight plant species in the field. Water, Air, and Soil Pollution 184 (1-4): 235-242. - doi: 10.1007/s11270-0079412-2 